\title{
ANALISIS FAKTOR-FAKTOR YANG MEMPENGARUHI EFFECTIVE TAX RATE
}

\author{
Diana Rimadani ${ }^{1}$, Suhendro ${ }^{2}$, Riana R Dewi ${ }^{3}$ \\ ${ }^{1}$ Universitas Islam Batik Surakarta, rimadanidiana28@gmail.com
}

\begin{abstract}
ABSTRAK
Penelitian ini bertujuan untuk mengetahui pengaruh ukuran perusahaan, profitabilitas, leverage dan capital intensity terhadap effective tax rate. Penelitian ini menggunakan data sekunder. Variabel dependen dalam penelitian ini yaitu effective tax rate, sedangkan variabel independen dalam penelitian ini yaitu ukuran perusahaan, profitabilitas, leverage dan capital intensity. Populasi penelitan ini adalah perusahaan infrastruktur, transportasi dan utilitas yang terdaftar dalam BEI periode 20162018. Sampel yang digunakan sebanyak 51 sampel. Teknik analisis data yang digunakan dalam penelitian ini yaitu dengan menggunakan analisis regresi linier berganda. Hasil dari penelitian ini menyatakan bahwa : 1) ukuran perusahaan berpengaruh terhadap effective tax rate, 2) profitabilitas tidak berpengaruh terhadap effective tax rate, 3) leverage tidak berpengaruh terhadap effective tax rate, 4) capital intensity berpengaruh terhadap effective tax rate.
\end{abstract}

Kata Kunci: Ukuran perusahaan, profitabilitas, leverage, capital intensity, effective tax rate

\begin{abstract}
This research aims to determine the influence of company size, profitability, leverage and capital intensity towards effective tax rate. This research uses secondary data. The dependent variable in this study is an effective tax rate, while independent variables in the study are company size, profitability, leverage and capital intensity. The population of this research is an infrastructure, transport and utilities company registered in the IDX period 2016-2018. Samples used as much as 51 samples. The data analysis techniques used in this study were by using multiple linear regression analyses. The results of the study stated that: 1) the size of the company affects effective tax rate, 2) profitability has no effect on the effective tax rate, 3) leverage has no effect on the effective tax rate, 4) capital intensity is influential on the effective tax rate.
\end{abstract}

Keywords: Firm Size, Profitability, Leverage, Capital Intensity, Effective Tax Rate

Naskah diterima: 31-08-2020, Naskah dipublikasikan: 30-11-2020

\section{PENDAHULUAN}

Pajak merupakan iuran wajib yang dibayarkan wajib pajak kepada negara. Bagi pemerintah dana pajak yang dibayarkan oleh wajib pajak merupakan pendapatan yang nantinya dana tersebut akan digunakan untuk membiayai pengeluaran rutin dan melakukan pembangunan nasional. Namun hal ini berbeda bagi wajib pajak khusunya wajib pajak badan, bagi wajib pajak pembayaran pajak merupakan sebuah beban yang harus ditanggung perusahaan dan akan mengurangi laba yang diperoleh perusahaan.

Pemerintah terus mengupayakan untuk meningkatkan pendapatan dari sektor pajak dengan cara mengeluarkan Undang-Undang No.36 Tahun 2008 Pasal 17 ayat (2b) yang berisi mengenai pemberian insentif penurunan tarif pajak dari pemerintah kepada wajib pajak badan dalam negeri. Selain itu pemerintah juga mengeluarkan Peraturan Pemerintah No 46 Tahun 2013 tentang penyederhanaan penghitungan pajak.

Penelitian yang dilakukan Ardyansah \& Zulaikha (2014) yang berlatar belakang pada perusahaan manufaktur yang terdaftar di Bursa Efek Indonesia menyatakan bahwa variabel size dan 
komisaris independen memiliki pengaruh terhadap effective tax rate, sedangkan variabel leverage, profitability dan capital intensity ratio menunjukkan hasil tidak memiliki pengaruh terhadap effective tax rate. Hal ini tidak jauh berbeda dengan penelitian Putri (2016) yang menyatakan bahwa ukuran perusahaan berpengaruh terhadap effective tax rate, sedangkan profitabilitas dan leverage tidak berpengaruh terhadap effective tax rate. Namun dalam penelitan Putri (2016) capital intensity berpengaruh terhadap effective tax rate. Penelitian tersebut tidak sejalan dengan penelitian yang dilakukan Imelia (2015) yang menyatakan bahwa ukuran perusahaan, profitabilitas, intensitas persediaan, intensitas aset tetap tidak berpengaruh signifikan terhadap manajemen pajak yang di ukur dengan menggunakan tarif pajak efektif (ETR), sedangkan hutang perusahaan, fasilitas perpajakan dan komisaris independen berpengaruh signifikan terhadap manajemen pajak perusahaan yang diukur dengan tarif pajak efektif (ETR).

Mendasarkan pada hasil penelitian tersebut maka peneliti akan menguji kembali pengaruh ukuran perusahaan, profitabilitas, leverage dan capital intensity terhadap effective tax rate.

\section{KAJIAN LITERATUR \\ Teori Stakeholder}

Teori stakeholder menunjukkan tanggung jawab perusahaan tidak hanya ditujukan untuk kesejahteraan perusahaan saja, melainkan juga tanggung jawab social yang harus dipertimbangkan dampaknya untuk semua pihak (Lako, 2011). Dalam teori stakeholder kinerja organisasi dipengaruhi oleh seluruh stakeholder. Stakeholder memiliki kekuasaan guna mempengaruhi pemakaian sumber ekonomi yang digunakan perusahaan (Donaldson \& Preston, 1995). Stakeholder sendiri dibagi menjadi dua kategori (Jones, 1995) : 1) Inside Stakeholder, merupakan orang-orang yang memiliki kepentingan dan tuntutan atas sumber daya perusahaan dan berada dalam organisasi perusahaan. 2) Outside Stakeholder, merupakan orang-orang yang bukan berasal dari lingkup perusahaan namun mereka memiliki kepentingan dengan perusahaan dan tindakan-tindakan yang diambil perusahaan akan berpengaruh terhadap mereka.

\section{Teori Agency}

Teori agency dalam penelitian ini digunakan untuk menjelaskan hubungan antara ukuran perusahaan, profitabilitas, leverage dan capital intensity terhadap effective tax rate. Perbedaan kepentingan antara fiskus dan perusahaan akan menimbulkan ketidakpatuhan yang dilakukan oleh wajib pajak yang dijalankan oleh manajemen perusahaan yang akan berdampak pada upaya perusahaan untuk melakukan manajemen pajak. Masalah agensi yang muncul dengan adanya manajemen pajak adalah karena adanya peningkatan kompensasi, sedangkan pemegang saham yang menginginkan penekanan biaya pajak (Martani, 2015)

\section{Perpajakan}

Pajak merupakan iuran rakyat kepada kas negara berdasarkan undang-undang (yang dapat dipaksakan) dengan tiada mendapat jasa timbal (kontraprestasi) yang langsung dapat ditunjukkan dan yang digunakan untuk membayar pengeluaran umum (Soemitro, 1992). Sistem pemungutan pajak yang digunakan di Indonesia adalah self assesment systemi dimana wajib pajak memiliki peran untuk menghitung, melaporkan dan membayarkan pajaknya sendiri. Kekurangan sistem ini adalah wajib pajak akan berusaha untuk menyetorkan pajaknya sekecil mungkin.

\section{Effective Tax Rate}

Darmadi \& Zulaikha (2013) mendefiniskan effective tax rate sebagai tarif yang sesungguhnya berlaku atas penghasilan wajib pajak. Sedangkan Paul \& Keefe III (2011) mendefiniskan effective tax rate sebagai rasio pajak yang dibayar untuk keuntungan sebelum pajak untuk periode tertentu.

\section{Ukuran Perusahaan}

Ukuran perusahaan merupakan suatu pengukuran yang dikelompokkan berdasarkan besar kecilnya perusahaan, dan dapat menggambarkan kegiatan operasional perusahaan dan pendapatan 
yang diperoleh perusahaan. Semakin besar ukuran dari sebuah perusahaan, kecenderungan perusahaan membutuhkan dana akan juga lebih besar dibandingkan perusahaan yang lebih kecil, hal ini membuat perusahaan yang besar cenderung menginginkan pendapatan yang besar (Ardyansah \& Zulaikha, 2014). Ukuran perusahaan diartikan sebagai suatu skala dimana dapat diklasifikasikan besar kecil perusahaan dengan berbagai cara antara lain dinyatakan dalam total aset, nilai pasar saham, dan lainlain (Putri, 2016).

\section{Profitabilitas}

Tujuan didirikannya sebuah perusahaan yaitu untuk mendapatkan profit semaksimal mungkin. Rasio profitabilitas digunakan untuk mengukur laba dan keberhasilan operas suatu perusahaan dalam suatu perode waktu tertentu. Laba (atau mungkin rugi) mempengaruhi kemampuan perusahaan untuk mendapat pendanaan utang atau ekuitas. Selain itu juga mempengaruhi posisi likuiditas perusahaan dan kemampuan perusahaan untuk berkembang. Oleh karena itu, baik kreditor maupun investor, sangat tertarik untuk mengevaluasi kemampuan perusahaan memperoleh laba (Jusup, 2011). Profitabilitas merupakan suatu indikator kinerja yang dilakukan manajemen dalam mengelola kekayaan perusahaan yang ditunjukkan oleh laba yang dihasilkan. Secara garis besar, laba yang dihasilkan perusahaan berasal dari penjualan dan investasi yang dilakukan oleh perusahaan (Sudarmadji \& Sularto, 2007).

\section{Leverage}

Leverage merupakan suatu perbandingan yang mencerminkan besarnya utang yang digunakan untuk pembiayaan oleh perusahaan dalam menjalankan aktivitas operasinya (Praditasari \& Setiawan, 2017). Penambahan jumlah hutang akan menyebabkan timbulnya beban bunga yang harus dibayar oleh perusahaan. Beban bunga yang timbul atas hutang tersebut akan menjadi pengurang laba bersih yang kemudian akan mengurangu pembayaran pajak sehingga akan tercapai keuntungan yang maksimal. Dalam UU No. 36 Tahun 2008 pasal 6 ayat 1a dan pasal 18 ayat 3 menjelaskan bahwa beban bunga yang hanya berasal dari pinjaman pihak ketiga atau kreditur yang dapat dijadikan pengurang laba kena pajak yang tidak memiliki hubungan dengan perusahaan (Hendy \& Sukartha, 2014)

\section{Capital Intensity}

Capital Intensity atau yang biasa disebut juga dengan Intensitas modal sering dikaitkan dengan seberapa besar modal yang dimiliki perusahaan berupa fixed asset. Capital Intensity juga merupakan salah satu bentuk keputusan keuangan dimana keputusan tersebut ditetapkan oleh manajemen perusahaan guna meningkatkan profitabilitas perusahaan (Mulyani dkk, 2014). Rodriguez \& Arias (2012) menyebutkan bahwa aktiva tetap yang dimiliki perusahaan memungkinkan perusahaan untuk memotong pajak akibat depresiasi dari aktiva tetap setiap tahunnya. Hal ini menunjukkan bahwa perusahaan yang memiliki tingkat aktiva tetap yang tinggi berarti memiliki beban pajak yang lebih rendah dibandingkan perusahaan yang memiliki aktiva tetap yang rendah. 


\section{JURNAL AKUNTANSI, Vol. 9 No. 2 November (2020)}

\section{Kerangka Konseptual Penelitian}

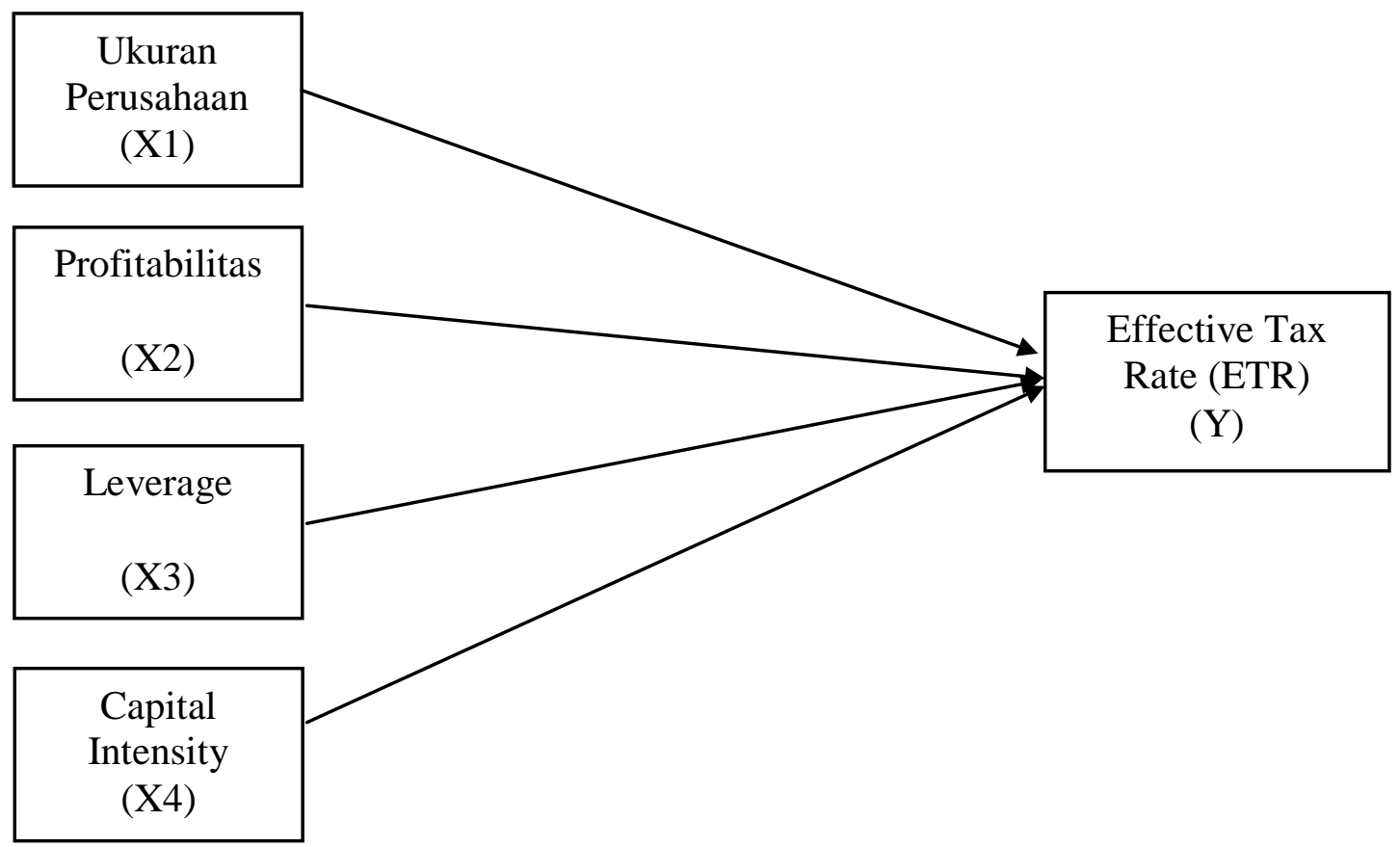

\section{Gambar 1. Kerangka Konseptual Penelitian}

1. Putri (2016), meneliti pengaruh ukuran perusahaan terhadap effective tax rate.

2. Janssen \& Wellem (2000), meneliti pengaruh profitabilitas terhadap effective tax rate.

3. Noor \& Mastuki (2008), meneliti pengaruh leverage terhadap effective tax rate.

4. Putri \& Lautania (2016), meneliti pengaruh capital intensity terhadap effective tax rate.

\section{PENELITIAN TERDAHULU}

Penelitian yang dilakukan oleh Putri (2016) pada perusahaan transportasi yang terdaftar di Bursa Efek Indonesia pada periode 2011-2013 menunjukkan hasil yang menyatakan bahwa ukuran perusahaan dan intensitas modal berpengaruh terhadap tarif pajak efektif, sedangkan untuk variabel return on asset (ROA) dan leverage tidak berpengaruh terhadap tarif pajak efektif.

Ardyansah \& Zulaikha (2014) melakukan penelitian pada perusahaan manufaktur yang terdaftar di Bursa Efek Indonesia pada periode 2010-2012. Penelitian ini menunjukkan hasil bahwa variabel size dan komisaris independen memiliki pengaruh terhadap effective tax rate (ETR), sedangkan untuk variabel bebas lainnya yaitu leverage, profitability, capital intensity ratio menunjukkan hasil tidak memiliki pengaruh terhadap effective tax rate (ETR).

Penelitian lain juga dilakukan oleh Noor \& Mastuki (2008), penelitian ini meneliti sepuluh sektor perusahaan yang terdaftar di dewan utama dan bursa Malaysia, perusahaan meliputi sektor industri, perdagangan dan jasa, produk konsumen, properti, perkebunan, konstruksi, teknologi, infrastruktur, hotel pertambangan dengan rentang periode pada tahun 2000-2004. Hasil dari penelitian ini menunjukkan bahwa ukuran perusahaan, leverage, return on asset (ROA) dan intensitas modal memiliki pengaruh terhadap effective tax rate (ETR).

Putri \& Lautania (2016) juga melakukan penelitian pada perusahaan manufaktur yang terdaftar dalam Bursa efek Indonesia pada periode 2011-2014. Hasil dalam penelitian tersebut capital intensity ratio, inventory intensity ratio, managerial ownership, institutional ownership, dan profitability berpengaruh secara bersama-sama terhadap ETR, capital intensity ratio dan inventory intensity ratio berpengaruh secara parsial terhadap ETR, sedangkan Managerial ownership dan institutional ownership tidak berpengaruh secara parsial terhadap ETR. 
Penelitian lain juga dilakukan oleh Ambarukmi \& Diana (2017) penelitian tersebut melakukan penelitian pada perusahaan LQ-45 yang terdaftar di Bursa Efek Indonesia selama periode 2011-2015. Hasil dalam penelitian tersebut yaitu Size berpengaruh signifikan positif terhadap effective tax rate, Leverage dan Profitability tidak berpengaruh signifikan positif terhadap effective tax rate, sedangkan capital intensity ratio berpengaruh tidak signifikan negative terhadap effective tax rate.

Penelitian yang dilakukan oleh Sjahril dkk (2020), penelitian tersebut meneliti perusahaan real estate \& property yang terdaftar dalam Bursa Efek Indonesia periode 2016-2018. Hasil dalam penelitian tersebut menunjukkan bahwa secara parsial leverage dan intensitas aset tetap berpengaruh negative terhadap tarif pajak efektif, sedangkan profitabilitas berpengaruh positif terhadap tarif pajak efektif.

Penelitian yang dilakukan oleh Damayanti \& Gazali (2019) penelitian tersebut meneliti tentang perusahaan konstruksi dan bangunan yang terdaftar di Bursa Efek Indonesia periode 20142017. Hasil dari penelitian ini menunjukkan bahwa Capital Intensity Ratio dan Profitability berpengaruh secara signifikan terhadap Effective Tax Rate. Sedangkan Leverage dan Size tidak berpengaruh secara signifikan terhadap Effective Tax Rate.

\section{PENGEMBANGAN HIPOTESIS}

Pengaruh Ukuran Perusahaan terhadap Effective Tax Rate (ETR)

Ukuran perusahaan merupakan suatu skala dimana sebuah perusahaan dapat diklasifikasikan besar atau kecilnya dengan berbagai cara. Perusahaan yang memiliki aset yang besar maka jumlah produktifitasnya akan ikut meningkat. Penelitian yang dilakukan oleh Rodriguez \& Arias (2012) menemukan bahwa ukuran perusahaan berpengaruh terhadap effective tax rate. Hal ini sejalan dengan penelitian yang dilakukan oleh Putri (2016) yang menunjukkan bahwa ukuran perusahaan berpengaruh effective tax rate. Perusahaan yang berskala besar akan memiliki sumber daya yang besar sehingga dapat digunakan untuk tujuan-tujuan tertentu seperti halnya sumber daya tersebut digunakan oleh manajer guna memaksimalkan kinerjanya dengan menekankan biaya pajak yang menjadi tanggungan perusahaan. Menurut penelitian tersebut, maka penulis menyatakan hipotesis pertama dalam penelitian ini yaitu:

\section{H1 : Ukuran Perusahaan berpengaruh terhadap Effective Tax Rate (ETR)}

\section{Pengaruh Profitability terhadap Effective Tax Rate (ETR)}

ROA menggambarkan kemampuan perusahaan dalam menghasilkan laba dengan menggunakan aset yang dimiliki perusahaan. Perusahaan yang memiliki kemampuan dalam memperoleh laba yang besar maka harus mempersiapkan pajak yang harus dibayarnya. Sehingga secara otomatis ROA akan mengakibatkan kenaikan pada effective tax rate. Penelitian yang dilakukan oleh Ardyansah \& Zulaikha (2014) menyatakan bahwa profitability berpengaruh terhadap efective tax rate. Hal ini sejalan dengan penelitian yang dilakukan oleh Janssen \& Wellem (2000) yang menyatakan bahwa terdapat pengaruh Return On Asset (ROA) terhadap effective tax rate. Menurut penelitian tersebut, maka penulis menyatakan hipotesis pertama dalam penelitian ini yaitu :

\section{H2 : Profitability berpengaruh terhadap Effective Tax Rate (ETR)}

\section{Pengaruh Leverage terhadap Effective Tax Rate (ETR)}

Leverage merupakan banyaknya jumlah utang yang dimiliki perusahaan dalam melakukan pembiayaan dan dapat digunakan untuk mengukur besarnya aset yang dibiayai dengan utang. hutang yang dimiliki perusahaan akan menghasilkan beban bunga yang mana beban bunga tersebut dapat digunakan perusahaan untuk mengurangi laba perusahaan. Penelitian yang dilakukan oleh Sjahril dkk, (2020) menyatakan bahwa leverage berpengaruh terhadap effective tax rate. Penelitian ini sejalan dengan penelitian yang dilakukan oleh Noor \& Mastuki (2008) yang menyatakan bahwa leverage memiliki pengaruh terhadap effective tax rate. Menurut penelitian tersebut, maka penulis menyatakan hipotesis pertama dalam penelitian ini yaitu :

\section{H3 : Leverage berpengaruh terhadap Effective Tax Rate (ETR)}




\section{Pengaruh Capital Intensity terhadap Effective Tax Rate (ETR)}

Capital Intensity merupakan aktivitas investasi yang dilakukan perusahaan yang berkaitan dengan investasi dalam bentuk aset tetap dan persediaan. Aset tetap yang dimiliki perusahaan akan mengalamai penyusutan dan beban penyusutan tersebut dapat mengurangu jumlah pajak yang dibayar perusahaan. Penelitian yang dilakukan oleh Putri \& Lautania (2016) menyatakan bahwa terdapat pengaruh antara Intensitas Modal (Capital Intensity) terhadap effective tax rate. Penelitian ini sejalan dengan penelitian yang dilakukan oleh Damayanti \& Gazali (2019). Menurut penelitian tersebut, maka penulis menyatakan hipotesis pertama dalam penelitian ini yaitu :

\section{H4 : Capital Intensity berpengaruh terhadap Effective Tax Rate (ETR)}

\section{METODE PENELITIAN}

Penelitian ini merupakan jenis penelitian kuantitatif deskriptif, dengan menggunakan sampel pada perusahaan sektor infrastruktur, transportasi dan utilitas yang terdaftar di Bursa Efek Indonesia pada periode pelaporan 2016-2018. Teknik pemilihan sampel yang digunakan dalam pemilihan sampel yaitu menggunakan teknik purposive sampling dengan menerapkan beberapa kriteria yang telah ditentukan. Kriteria yang telah ditentukan dalam pengambilan sampel diantaranya :

a. Perusahaan Infrastruktur, Transportasi dan Utilitas yang terdaftar di BEI pada tahun 2016-2018.

b. Perusahaan yang menerbitkan laporan tahunan (annual report) perusahaan selama periode penelitian yaitu periode 2016-2018.

c. Perusahaan yang mengalami laba selama periode penelitian yaitu 2016-2018.

d. Perusahaan yang mengalami laba selama periode penelitian yaitu 2016-2018.

Kemudian data di analisis dengan menggunakan metode analisis regresi linier berganda, dengan model regresi sebagai berikut :

$$
\mathrm{Y}=\mathrm{a}+\beta 1 \mathrm{X} 1+\beta 2 \mathrm{X} 2+\beta 3 \mathrm{X} 3+\beta 4 \mathrm{X} 4+\mathrm{e}
$$

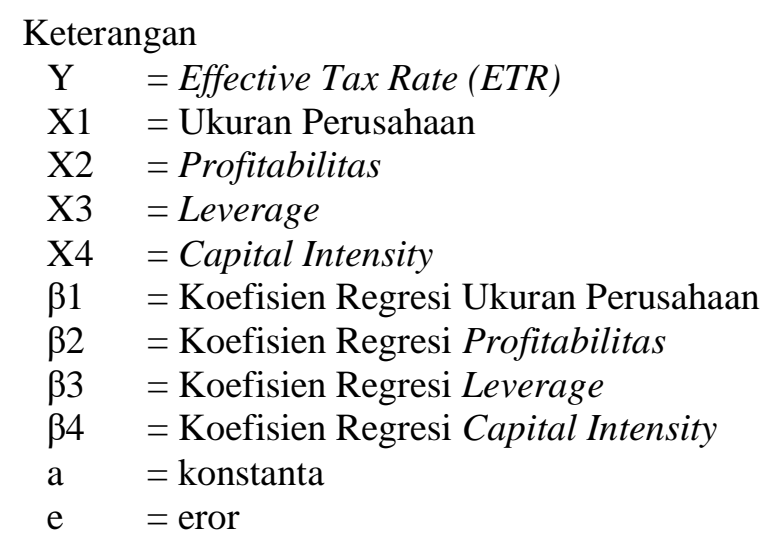




\section{JURNAL AKUNTANSI, Vol. 9, No. 2 November (2020)}

\section{HASIL DAN PEMBAHASAN}

Analisis Statistik Deskriptif

Uji statistik deskriptif digunakan untuk mengetahui nilai mean, maksimum, minimum dan standar deviasi. Hasil uji analysis statistic deskriptif juga dapat digunakan untuk mengetahui penyebaran datanya baik atau tidak. Berikut hasil uji statistik deskriptif :

Tabel 1. Statistik Deskriptif

\begin{tabular}{lccccc}
\hline & & & & & Std. \\
& N & Min & Max & Mean & Deviation \\
\hline Effective Tax Rate & 51 & 0,03 & 0,39 & 0,1973 & 0,09982 \\
$\quad$ Ukuran Perusahaan & 51 & 12,65 & 19,14 & 15,3314 & 1,75062 \\
Profitabilitas & 51 & 0,00 & 0,20 & 0,0647 & 0,04835 \\
Leverage & 51 & 0,08 & 13,54 & 1,7276 & 2,21780 \\
Capital Intensity & 51 & 0,01 & 0,95 & 0,5582 & 0,30877 \\
& 51 & & & & \\
$\quad$ Valid N (listwise) & & & & & \\
\hline
\end{tabular}

\section{Uji Asumsi Klasik}

\section{Uji Normalitas}

Uji normalitas digunakan untuk menguji apakah dalam model regresi, variabel penggangu atau residual terdistribusi secara normal. Untuk menguji normalitas data maka dalam penelitian ini menggunakan uji Kolmogrov-Smirnov (K-S). Berikut adalah hasil uji normalitas dengan menggunakan Kolmogrov-Smirnov (K-S) :

Tabel 2. One Sample Kolmogrov-Smirnov Test

\begin{tabular}{lccc}
\hline & Asymp Sig & Kriteria & Keterangan \\
\hline $\begin{array}{l}\text { Unstandardized } \\
\text { Residual }\end{array}$ & 0,200 & $>0,05$ & $\begin{array}{c}\text { Data terdistribusi } \\
\text { normal }\end{array}$ \\
\hline
\end{tabular}

\section{Uji Multikolinearitas}

Uji multikolinearitas dilakukan dengan tujuan untuk menguji apakah dalam model regresi ditemukan adanya korelasi antar variabel bebas. Uji multikolinearitas dilihat dari nilai tolerance dan variance inflation factor (VIF). Nilai standar untuk menunjukkan terjadinya multikolinearitas atau tidak yaitu nilai tolerance $>0,10$ dan nilai VIF $<10,00$. Berikut ini adalah tabel hasil pengujian multikolinearitas :

Tabel 3. Uji Multikolinearitas

\begin{tabular}{|c|c|c|c|c|c|}
\hline Variabel & Tolerance & Standart & VIF & Standart & Keterangan \\
\hline $\begin{array}{l}\text { Ukuran } \\
\text { Perusahaan }\end{array}$ & 0,836 & $>0,10$ & 1,136 & $<10,00$ & $\begin{array}{c}\text { Tidak terjadi } \\
\text { multikoliniearitas }\end{array}$ \\
\hline Profitabilitas & 0,916 & $>0,10$ & 1,092 & $<10,00$ & $\begin{array}{c}\text { Tidak terjadi } \\
\text { multikoliniearitas }\end{array}$ \\
\hline Leverage & 0,859 & $>0,10$ & 1,164 & $<10,00$ & $\begin{array}{c}\text { Tidak terjadi } \\
\text { multikoliniearitas }\end{array}$ \\
\hline $\begin{array}{l}\text { Capital } \\
\text { Intensity }\end{array}$ & 0,885 & $>0,10$ & 1,129 & $<10,00$ & $\begin{array}{c}\text { Tidak terjadi } \\
\text { multikolinearitas }\end{array}$ \\
\hline
\end{tabular}




\section{Uji Autokorelasi}

Uji autokorelasi bertujuan untuk menguji apakah dalam suatu model regresi liniear terdapat korelasi antara kesalahan penggunaan pada periode t dengan kesalahan pengganggu pada periode sebelumnya (t-1). Untuk mengetahui ada tidaknya autokorelasi maka dilakukan pengujian autokorelasi dengan menggunakan statistic Durbin Watson (D-W) (Ghozali, 2011). Berikut adalah hasil pengujian uji autokorelasi :

Tabel 4. Uji Autokorelasi

\begin{tabular}{llllllll}
\hline Model & Du & $\begin{array}{l}\text { Durbin- } \\
\text { Watson }\end{array}$ & 4-du & 4-dl & Keterangan & & \\
\hline 1 & $1,7218<$ & 1,798 & $<2,2782$ & $2,6145 \quad \begin{array}{l}\text { Bebas auto } \\
\text { digunakan }\end{array}$ & atau & Layak \\
\hline
\end{tabular}

\section{Uji Heterokedastisitas}

Tujuan dilakukannya uji heterokedastisitas yaitu untuk menguji apakah dalam model regresi terjadi ketidaksamaan variance dari residual satu pengamatan ke pengamatan yang lain. Dalam penelitian ini uji heterokedastisitas dilakukan dengan melihat grafik scatterplot, berikut adalaha grafik dari uji heterokedastisitas :

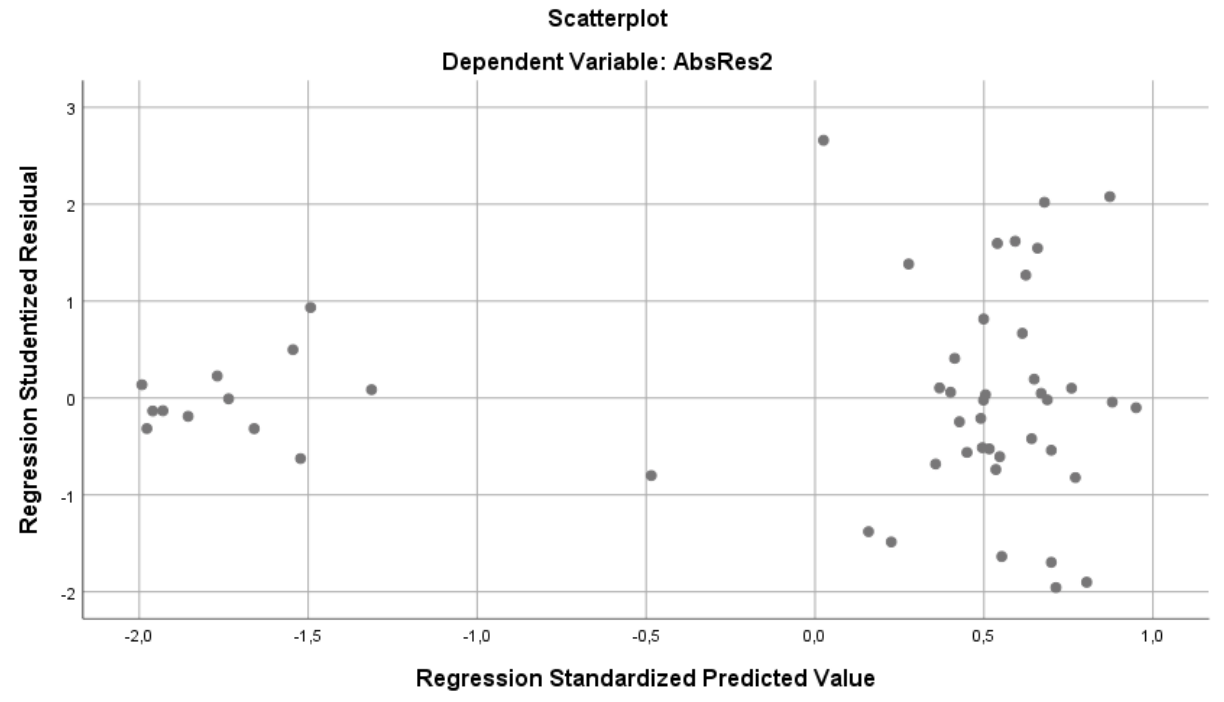

Grafik 1. Uji Heterokedastisitas

\section{Analisis Regresi}

\section{Persamaan Regresi}

Penelitian ini menggunakan regresi liniear berganda, regresi liniear berganda berfungsi untuk menguji pengaruh dua atau lebih variabel independen terhadap satu variabel dependen . Berikut adalah hasil uji analisis regresi linier berganda :

Tabel 5. Hasil Uji Regresi Linier Berganda

\begin{tabular}{lcc}
\hline \multirow{2}{*}{ Model } & Unstandardized Coefficients & \\
& $\mathrm{B}$ & Sig. \\
\hline (Constant) & $-10,763$ & 0,012 \\
Ukuran Perusahaan & 0,721 & 0,009 \\
Profitabilitas & $-0,050$ & 0,806 \\
Leverage & $-0,114$ & 0,609 \\
Capital Intensity & 0,468 & 0,017 \\
\hline
\end{tabular}




\section{JURNAL AKUNTANSI, Vol. 9, No. 2 November (2020)}

Dari hasil tersebut maka di dapat model persamaan regresi seperti berikut :

$$
Y=-10,763+0,721 X 1-0,50 X 2-0,114 X 3+0,468 X 4
$$

\section{Uji Kelayakan Model (Uji F)}

Uji signifikansi simultan (uji statistic F) dilakukan dalam tingkat signifikansi 0,05. Jika nilai signifikansi $\mathrm{F}$ lebih besar dari 0,05 maka $\mathrm{H}_{0}$ diterima dan $\mathrm{H}_{\mathrm{a}}$ ditolak, sebaliknya jika nilai signifikansi F lebih kecil dari 0,05 maka $\mathrm{H}_{0}$ ditolak dan $\mathrm{H}_{\mathrm{a}}$ diterima. Berikut adalah hasil uji $\mathrm{F}$ :

Tabel 6. Hasil Uji F

\begin{tabular}{llllll}
\hline Model & $\mathrm{F}_{\text {hitung }}$ & $\mathrm{F}_{\text {tabel }}$ & Sig & Kriteria & Keterangan \\
\hline 1 & 4,323 & $>2,57$ & 0,005 & $<0,05$ & Model Layak \\
\hline
\end{tabular}

\section{Uji hipotesis (Uji t)}

Uji statistic t dilakukan untuk menunjukkan seberapa juah pengaruh satu variabel independen secara individual mempengaruhi variabel dependen (Ghozali, 2005). Adapun tingkat signifikansi yang digunakan dalam penelitian ini yaitu 0,05. Berikut merupakan hasil uji t :

Tabel 7. Hasil Uji-t

\begin{tabular}{lccccc}
\hline Hipotesis & $\mathrm{t}_{\text {hitung }}$ & $\mathrm{t}_{\text {tabel }}$ & Sig & Kriteria & Keterangan \\
\hline $\begin{array}{l}\text { Ukuran } \\
\text { Perusahaan }\end{array}$ & 2,742 & 0,679 & 0,009 & $<0,05$ & Diterima \\
$\begin{array}{l}\text { Profitabilitas } \\
\text { Leverage }\end{array}$ & $-0,246$ & 0,679 & 0,806 & $<0,05$ & Ditolak \\
$\begin{array}{l}\text { Capital } \\
\text { Intensity }\end{array}$ & $-0,516$ & 0,679 & 0,609 & $<0,05$ & Ditolak \\
\hline
\end{tabular}

\section{Koefisien Determinasi $\left(\mathbf{R}^{2}\right)$}

Uji koefisien determinasi $\left(\mathrm{R}^{2}\right)$ pada intinya mengukur seberapa jauh kemampuan model dalam menerangkan variasi variabel dependen. Pengujian koefisien determinasi $\left(\mathrm{R}^{2}\right)$ dalam penelitian ini dilakukan guna mengukur variabel independen yaitu ukuran perusahaan, profitabilitas, leverage, capital intensity dalam menjelaskan va

Tabel 8. Koefisien Determinan

\begin{tabular}{lll}
\hline Model & Adjusted $R$ Square & Keterangan \\
\hline 1 & 0.210 & Pengaruh ukuran perusahaan, profitabilitas, \\
& leverage dan capital intensity terhadap effective \\
& tax rate sebesar $21 \%$ sedangkan sisanya $79 \%$ \\
& dipengaruhi oleh variabel lain \\
\hline
\end{tabular}

\section{Pembahasan}

Berdasarkan pegujian yang telah dilakukan, maka penelitian ini menunjukkan hasil bahwa ukuran perusahaan berpengaruh terhadap effective tax rate. Hal ini terlihat dari tabel 7 yang tertera pada uji-t, dalam tabel tersebut menunjukkan nilai signifikansi dari variable ukuran perusahaan sebesar 0,009 yang artinya nilai tersebut lebih kecil dari criteria yaitu $0,05(0009<0,05)$ dan nilai t hitung sebesar 2,742 dan t tabel sebesar 0,679, artinya nilai t hitung lebih besar dari nilai t tabel. Hipotesis pertama dalam penelitian ini yaitu ukuran perusahaan berpengaruh terhadap effective tax rate. Dengan demikian hipotesis pertama dalam penelitian ini diterima. Hasil penelitian ini sejalan dengan penelitian yang dilakukan Putri (2016) yang menyatakan bahwa ukuran perusahaan berpengaruh terhadap tarif pajak efektif, juga penelitian yang dilakukan Ardyansah \& Zulaikha (2014) 
yang menyatakan bahwa size berpengaruh terhadap effective tax rate. Namun hasil penelitian ini tidak sejalan dengan penelitian yang dilakukan oleh Imelia (2015) yang menyatakan bahwa ukuran perusahaan tidak berpengaruh terhadap manajemen pajak yang diukur menggunakan tarif pajak efektif.

Kemudian pegujian yang telah dilakukan untuk variabel profitabilitas, menunjukkan hasil bahwa profitabilitas tidak berpengaruh terhadap effective tax rate. Hal ini terlihat dari tabel 7 yang tertera pada uji-t, dalam tabel tersebut menunjukkan nilai signifikansi dari variable profitabilitas sebesar 0,806 yang artinya nilai tersebut lebih besar dari kriteria yaitu $0,05(0,806>0,05)$ dan nilai $t$ hitung sebesar -0,246 dan $t$ tabel sebesar 0,679, artinya nilai t hitung lebih kecil dari nilai $t$ tabel. Hipotesis kedua dalam penelitian ini yaitu profitabilitas tidak berpengaruh terhadap effective tax rate. Dengan demikian hipotesis kedua dalam penelitian ini ditolak. Hasil penelitian ini sejalan dengan penelitian yang dilakukan oleh Ambarukmi \& Diana (2017) yang menyatakan bahwa profitability tidak berpengaruh terhadap effective tax rate. Hasil penelitian ini tidak sejalan dengan penelitian yang dilakukan oleh Sjahril, Yasa, \& Dewi (2020) menyatakan bahwa profitabilitas berpengaruh positif terhadap tarif pajak efektif, dan juga penelitian yang dilakukan oleh Damayanti \& Gazali (2019) yang menyatakan bahwa profitability berpengaruh secara signifikan terhadap effective tax rate.

Pengujian yang dilakukan untuk variabel leverage, menunjukkan hasil bahwa leverage tidak berpengaruh terhadap effective tax rate. Hal ini terlihat dari tabel 7 yang tertera pada uji-t, dalam tabel tersebut menunjukkan nilai signifikansi dari variable leverage sebesar 0,609 yang artinya nilai tersebut lebih besar dari kriteria yaitu 0,05 $(0,609>0,05)$ dan nilai t hitung sebesar -0,516 dan t tabel sebesar 0,679, artinya nilai t hitung lebih kecil dari nilai t tabel. Hipotesis ketiga dalam penelitian ini yaitu leverage tidak berpengaruh terhadap effective tax rate. Dengan demikian hipotesis ketiga dalam penelitian ini ditolak. Hasil penelitian ini sejalan dengan penelitian yang dilakukan oleh Setiawan \& Al-Ahsan (2016) yang menyatakan leverage tidak berpengaruh terhadap effective tax rate. Hasil penelitian ini tidak sejalan dengan penelitian yang dilakukan oleh Noor \& Mastuki (2008) yang menyatakan bahwa leverage memiliki pengaruh terhadap effective tax rate.

Berdasarkan pegujian yang telah dilakukan, maka penelitian ini menunjukkan hasil bahwa capital intensity berpengaruh terhadap effective tax rate. Hal ini terlihat dari tabel 7 yang tertera pada uji-t, dalam tabel tersebut menunjukkan nilai signifikansi dari variable capital intensity sebesar 0,017 yang artinya nilai tersebut lebih kecil dari kriteria yaitu $0,05(0,017<0,05)$ dan nilai t hitung sebesar 2,467 dan t tabel sebesar 0,679, artinya nilai t hitung lebih besar dari nilai t tabel. Hipotesis keempat dalam penelitian ini yaitu capital intensity berpengaruh terhadap effective tax rate. Dengan demikian hipotesis keempat dalam penelitian ini diterima. Hasil penelitian ini sejalan dengan penelitian yang dilakukan oleh Damayanti \& Gazali (2019) yang menyatakan capital intensity ratio berpengaruh secara signifikan terhadap effective tax rate, dan juga penelitian yang dilakukan oleh Putri \& Lautania (2016) yang menyatakan bahwa capital intensity ratio berpengaruh secara parsial terhadap effective tax rate. Namun hasil penelitian ini tidak sejalan dengan penelitian yang dilakukan oleh Ardyansah \& Zulaikha (2014) yang menyatakan bahwa capital intensity tidak berpengaruh terhadap effective tax rate.

\section{PENUTUP}

Penelitian ini dilakukan dengan tujuan untuk menguji dan menganalisa pengaruh ukuran perusahaan, profitabilitas, leverage dan capital intensity. Sampel yang digunakan dalam penelitian ini yaitu sebanyak 17 perusahaan infrastruktur, transportasi dan utilitas yang terdaftar di Bursa Efek Indonesia pada periode 2016-2018. Data tersebut diolah menggunakan analisis regresi liniear berganda. Jumlah observasi data sebanyak 51.

Merujuk pada hasil analisis, pengujian dan pembahasan maka dapat dikemukakan kesimpulan penelitian yaitu ukuran perusahaan berpengaruh terhadap effective tax rate. Hasil penelitian ini sejalan dengan penelitian yang dilakukan oleh Putri (2016) yang menyatakan bahwa ukuran perusahaan berpengaruh terhadap tarif pajak efektif, juga penelitian yang dilakukan oleh Ardyansah \& Zulaikha (2014) yang menyatakan bahwa size berpengaruh terhadap effective tax rate. Kemudian untuk variabel profitabilitas tidak berpengaruh terhadap effective tax rate. Hasil penelitian ini sejalan dengan 
penelitian yang dilakukan oleh Sjahril, Yasa, \& Dewi (2020) menyatakan bahwa profitabilitas berpengaruh positif terhadap tarif pajak efektif, dan juga penelitian yang dilakukan oleh Damayanti \& Gazali (2019) yang menyatakan bahwa profitability berpengaruh secara signifikan terhadap effective tax rate.

Variabel leverage tidak berpengaruh terhadap effective tax rate. Hasil penelitian ini sejalan dengan penelitian yang dilakukan oleh Noor \& Mastuki (2008) yang menyatakan bahwa leverage memiliki pengaruh terhadap effective tax rate. Sedangkan variabel Capital Intensity berpengaruh terhadap effective tax rate. Hasil penelitian ini sejalan dengan penelitian yang dilakukan oleh Damayanti \& Gazali (2019) yang menyatakan capital intensity ratio berpengaruh secara signifikan terhadap effective tax rate, dan juga penelitian yang dilakukan Putri \& Lautania (2016) yang menyatakan bahwa capital intensity ratio berpengaruh secara parsial terhadap effective tax rate.

\section{REFERENSI}

Ambarukmi, K. T., \& Diana, N. (2017). Pengaruh Size, Leverage, Profitability, Capital Intensity Ratio dan Activity Ratio Terhadap Effective Tax Rate (ETR) (Studi Empiris Pada Perusahaan LQ-45 Yang Terdaftar di BEI Selama Periode 2011-2015). e-Jurnal Ilmiah Riset Akuntansi Vol. 06 No. 17, 13-26.

Ardyansah, D., \& Zulaikha. (2014). Pengaruh Size, Leverage, Profitability, Capital Intensity dan Komisaris Independen terhadap Effective Tax Rate(ETR). Diponegoro Journal of Accounting Vol.3 , 1-9.

Damayanti, T., \& Gazali, M. (2019). Pengaruh Capital Intensity Ratio, Leverage, Profitability, dan Size Terhadap Effective Tax Rate Pada Perusahaan Konstruksi dan Bangunan Yang Terdaftar di BE Tahun 2014-2017. Prosiding Seminar Nasional Pakar ke 2.

Darmadi, I. N., \& Zulaikha. (2013). Analisis Faktor yang Mempengaruhi Manajemen Pajak dengan Indikator Tarif Pajak Efektif (Studi Empiris pada Perusahaan Manufaktur yang Terdaftar di Bursa Efek Indonesia pada Tahun 2011-2012). Diponegoro Journal of Accounting, Vol. 2, No. 4, 1-12.

Donaldson, T., \& Preston, L. (1995). The Stakeholder Theory of The Corporation : Concepts, Evidence, and Implications. The Academy of Management Review, Vol.20, No. 1, 65-91.

Ghozali, I. (2005). Aplikasi Analisis Multivariate dengan SPSS. Semarang: Badan Penerbit UNDIP.

Ghozali, I. (2011). Aplikasi Analisis Multivariate dengan Program SPSS. Semarang: Badan Penerbit Universitas Diponegoro.

Hendy, I. D., \& Sukartha, I. (2014). Pengaruh Penerapan Corporate Governance, Leverage, Return On Assets, dan Ukuran Perusahaan pada Penghindaran Pajak. E-Jurnal Akuntansi Universitas Udayana. Vol. 9, No. 1, 143-161.

Imelia, S. (2015). Analisis Faktor yang Mempengaruhi Manajemen Pajak dengan Indikator Tarif Pajak Efektif (ETR) pada Perusahaan LQ45 yang Terdaftar dalam Bursa Efek Indonesia Tahun 2010-2012. Jom FEKON Vol. 2 No. 1, 1-15.

Janssen, B. J., \& Wellem, B. (2000). Determinants of the Variability of Corporate Effective Tax Rates (ETRs) Evidence for the Netherlands. Mark Working Paper.

Jones, G. (1995). Organizational Theory: Text and Cases. Amerika Serikat: Addison Wesley.

Jusup, A. (2011). Dasar-Dasar Akuntansi Jilid 2. Yogyakarta: Bagian Penerbitan Sekolah Tinggi Ilmu Ekonomi YKPN.

Lako, A. (2011). Dekonstruksi CSR dan Reformasi Paradigma Bisnis dan Akuntansi. Jakarta: Erlangga.

Martani. (2015). Pengaruh Tax Avoidance terhadap Cost of Debt. Simposium Nasional Akuntansi XV, Banjarmasin.

Mulyani, S., Darminto, \& Endang , N. M. (2014). Pengaruh Karakteristik Perusahaan, Koneksi Politik dan Reformasi Perpajakan Terhadap Penghindaran Pajak (Studi pada Perusahaan Manufaktur yang Terdaftar di Bursa Efek Tahun 2008-2012). Jurnal Mahasiswa Perpajakan 2(1), 1-9. 
Noor, R. M., \& Mastuki, N. A. (2008). Corportae Effective Tax Rates : A Study on Malaysian Public Listed Companies. Malaysian Accounting Review, Vol.7 No. 1, 1-20.

Paul, R., \& Keefe III, J. D. (2011). Principles of Food Beverage and Labor Cost Control. New Jersey: Jhon Wiley \& Sons, Inc.

Praditasari, A., \& Setiawan, P. E. (2017). Pengaruh Good Corporate Governance, Ukuran Perusahaan, Leverage dan Profitabilitas pada Tax Avoidance. E-Jurnal Akuntansi, 19(2), 1229-1258.

Putri, C. L., \& Lautania, M. F. (2016). Pengaruh Capital Intensity Ratio, Inventory Ratio, Ownership Structure dan Profitability Terhadap Effective Tax Rate (ETR). Jurnal Ilmiah Mahasiswa Ekonomi Akuntansi Vol.1, No.1, 101-119.

Putri, S. E. (2016). Pengaruh Ukuran Perusahaan, Return On Asset (ROA), Leverage dan Intensitas Modal terhadap Tarif Pajak Efektif (Studi empiris pada perusahaan transportasi yang terdaftar di Bursa Efek Indonesia periode 2011-2013). JOM Fekon, Vol.3 No. 1, 1506-1519.

Rodriguez, E. F., \& Arias, A. M. (2012). Do Business Characteristics Determine an Effective Tax Rate. Chinese Economy 45(6), 60-83.

Setiawan, A., \& Al-Ahsan, M. K. (2016). Pengaruh Size, Leverage, Profitability, Komite Audit, Komisaris Independen dan Investor Konstitusional terhadap Effective Tax Rate (ETR). Jurnal EKA CIDA Vol. 1 No. 2 , 1-16.

Sjahril, R. F., Yasa, I. P., \& Dewi, G. K. (2020). Analisis Faktor-Faktor yang Mempengaruhi Tarif Pajak Efektif pada Wajib Pajak Badan (Studi Perusahaan Real Estate \& Property yang Terdaftar di Bursa Efek Indonesia Periode 2016-2018). JIMAT (Jurnal Ilmiah Mahasiswa Akuntansi) Universitas Pendidikan Ganesha, Vol: 11 No: 1, 56-65.

Soemitro, R. (1992). Dasar-Dasar Hukum Pajak dan Pajak Pendapatan 1994. Bandung: PT Eresco.

Sudarmadji, A. M., \& Sularto, L. (2007). Pengaruh Ukuran Perusahaan, Profitabilitas, Leverage dan Tipe Kepemilikan Perusahaan terhadap Luas Voluntary Disclosure Laporan Keuangan Tahunan. Proceding PESAT (Psikologi, Ekonomi, Sastra, Arsitek \& Sipil). 